The Journal of Public Space

ISSN 2206-9658

2019 | Vol. 4 n. 3

https://www.journalpublicspace.org

\title{
To Build the City on Temporary Success
}

Zala Velkavrh, Alenka Korenjak, Klara Otorepec, Maša Cvetko

prostoRož

info@prostoroz.org

\begin{abstract}
Some urban spaces are more dynamic than others. While the city centre, suburban areas and consumption spaces are rapidly changing and re-shaping, other parts of our cities seem to be stuck in time, in a permanent standstill. Such areas include stagnant construction sites, green areas and public squares in old housing estates and many forgotten, marginal public spaces scattered across the city. Conventional planning tools might be too slow, too weak or too broad to revitalise such spaces. We propose a different, interventionist approach. Temporary interventions have the power to change the planning process, involve more people and require less time.
\end{abstract}

Keywords: urban intervention, urban regeneration, public space, temporary urbanism

To cite this article:

Velkavrh, Z., Korenjak, A., Otorepec, K., Cvetko, M. (2019). To Build the City on Temporary Success, The Journal of Public Space, 4(3), 4I-60, DOI I0.3289I/jps.v4i3.I220

This article has been double blind peer reviewed and accepted for publication in The Journal of Public Space.

(c) (i) This work is licensed under a Creative Commons Attribution - Non Commercial 4.0 International License https://creativecommons.org/licenses/by-nc/4.0/ 


\section{Forgotten Public Space / Forgotten People}

In the past 15 years prostoRož has worked on more than 70 projects: exhibitions, actions, events, interventions, workshops and long-term revitalizations in Slovenia and abroad. We approach our projects differently: some start based on our own observations, some with the invitation of local civic sector, some are initiated by the city government and other decision makers. While our work has always been informed by international currents in urban design and participatory planning, it has also been focused on specific spatial, political and administrative issues in our locality. For example, our first project, revitalisations in the historic city centre of Ljubljana, made sense to us in 2004 , and makes none today due to rapid touristification. Today, regeneration of public space in estates built during socialism is one of our prime concerns. Renewal in these neighbourhoods is hindered by a range of obstacles in the fields of finance, ownership, urban planning, maintenance, legislation, social values and communication.

\section{Urbanism Camouflaged as Art}

prostoRož believes that public space must be accessible to all social groups, and we strive to understand the multitude of ways in which public space can be used. We want to contribute to the co-creation of quality public spaces that support the individuals who work in them. Such spaces are flexible and democratic, allowing for change and spontaneity. Early on, we discovered that we can overcome many legal restrictions and bureaucratic hurdles by branding our activity as "art". The main aim of our interventions has been clear from the very beginning: to regenerate open public space as common space, to preserve the existing qualities and to convince people to spend more time outdoors. Often our interventions feature loud colours and bold designs. Following the famous quote of American sociologist William $\mathrm{H}$. Whyte - "What attracts people most, it would appear, is other people" - we design interventions to attract people. However, each intervention has a rather dull counterpart: a plan, a list of maintenance improvements, meeting minutes and other tools commonly found in the 'bureaucratic toolkit'. Often, a lot of work is done to achieve important long-term changes that seem almost invisible in comparison with bold temporary interventions.

\section{New Experience of Space and Communication}

Tactical interventions have been deservedly criticised in the context of the gentrifying Western neoliberal cities. However, temporary interventions still prove effective for spaces in a need of re-boot. In I:I scale, stakeholders are able to experience one of the possible futures for open public space. In return, they are less likely to surrender the space to decay, uncontrolled development or, as has too often been the case, to coincidence. Our work shows that public space can be improved by a light intervention regardless of fragmented ownership, dispersed responsibility and the lack of funding for renewal. Users of a busy street can test how a shift to pedestrian traffic will change their everyday routines. Last but not least, temporary interventions enable urban planners and citizens to experience new forms of participation and collaboration. Quick, low budget and temporary interventions in public space can act as a catalyst for longterm regeneration until financial and regulatory requirements for renewal are met. 


\section{The Interplay between Temporary and Permanent}

"Urban art" as practiced by prostoRož does not address just the city dwellers, but also decision-makers. Temporary interventions without a long-term plan are mere empty gestures. However, as a first step in a long-term renewal process, they have the power to establish a link between residents, planners and local decision-makers, easing the way for permanent improvement. Moreover, they can restore the common communicative and physical space. The multitude of actors involved in a tactical intervention repositions open public space as common space and opens new scenarios for permanent renewal and a well-informed long-term collaboration. Experience from prostoRož's projects show that the success of a tactical intervention depends on several factors. Among the most important ones are the size of the area and an open attitude towards public participation. Practitioners should engage in open discussion about the present and future of public space, meet with local residents and stakeholders, learn about their wishes and present them the goals of their project. What is often forgotten are the limitations of temporary urbanism. Spatial and social problems need to be simple (or simplified) enough to be addressed with a temporary intervention. The dedication to improve the quality of urban life in the long-term is even more important. As much as temporary interventions can provide a foundation for creating a just, fun and accessible city, their success can only truly resonate if there is a clear vision for the city's future.

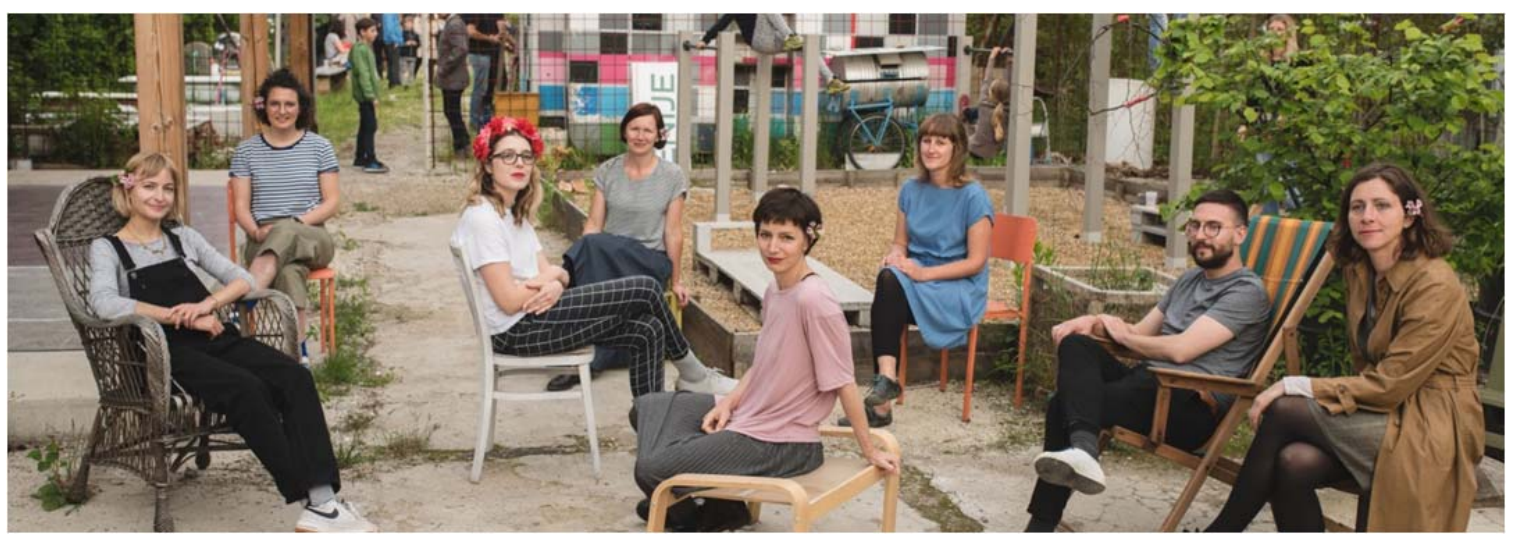

\section{prostoRož}

The mission of prostoRož cultural association is to improve public urban space. We explore public spaces in cities and their meaning for local residents and the society at large. We pay attention to overlooked public spaces and organize, rearrange and revitalize them according to the needs of residents and visitors. prostoRož was spontaneously formed in 2004 in Slovenia by three architects who wanted to improve the public space in their own city. Today it consists of architects, urbanists, sociologists, lawyers and other technical co-workers and focuses. We are the first organization in Slovenia to receive the public service status in the field of space, based on our work.

http://prostoroz.org/ 
To Build the City on Temporary Success

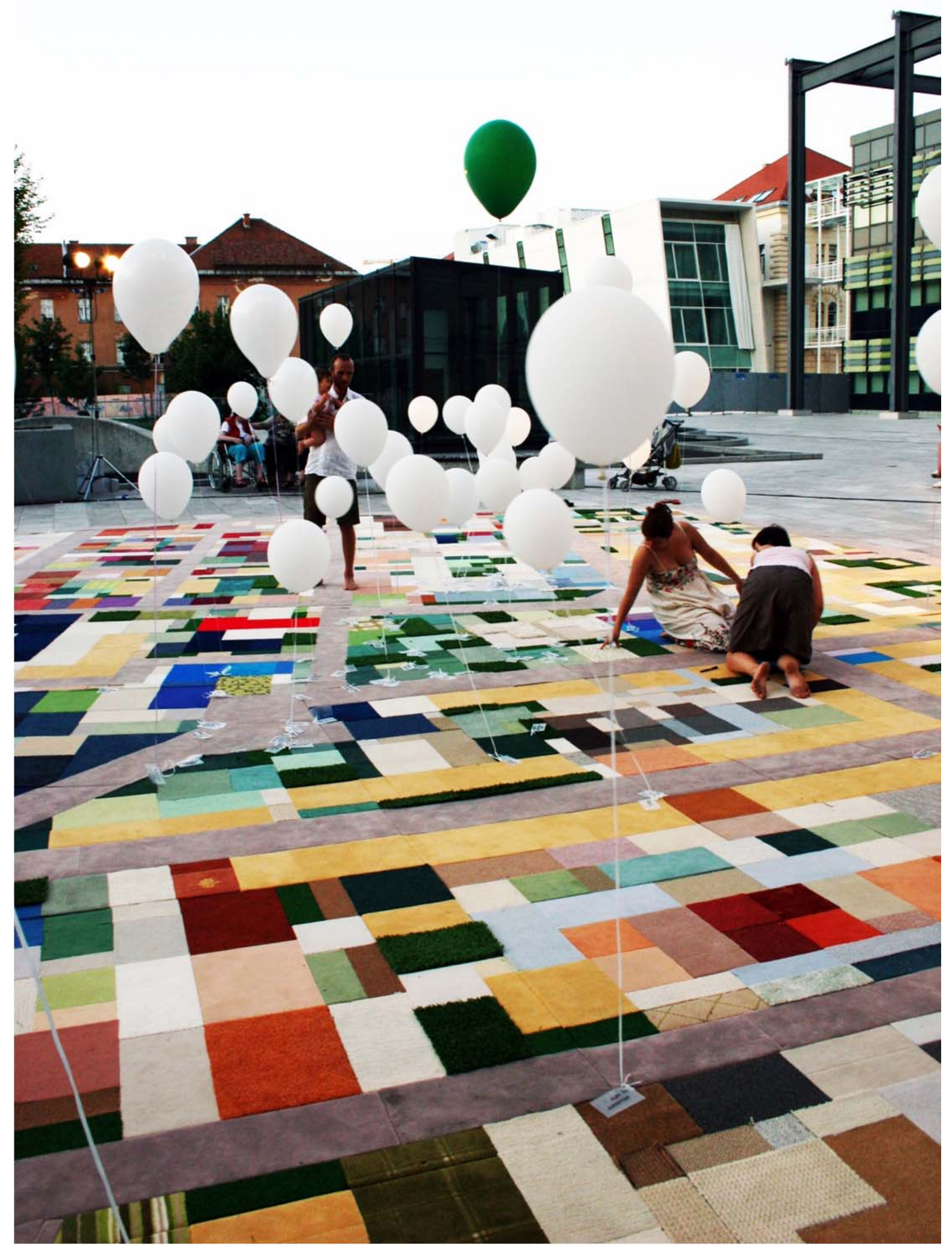

44 | The Journal of Public Space, 4(3), 2019 | ISSN 2206-9658

City Space Architecture / UN-Habitat 


\section{Map of wishes}

$(2011)$

Photo credit: Urška Bojkovac

We placed a 150 sqm large carpet in front of Slovene Ethnographic Museum - a map representing the Tabor quarter in Ljubljana. Individual colours on the carpet represented current usage of ground floor. Residents of the quarter as well as the visitors were invited to the carpet. They were able to state their wishes or make suggestions for the neighbourhood. At the end of the fifth day, there were around 200 wishes on the carpet. The mayor of Ljubljana went over the suggestions and announced what city council of Ljubljana will implement by the end of the year.As promised, Tabor quarter got two new playgrounds. The project was carried out as a part of long-term revitalization programme of Tabor Park in cooperation with Bunker association.

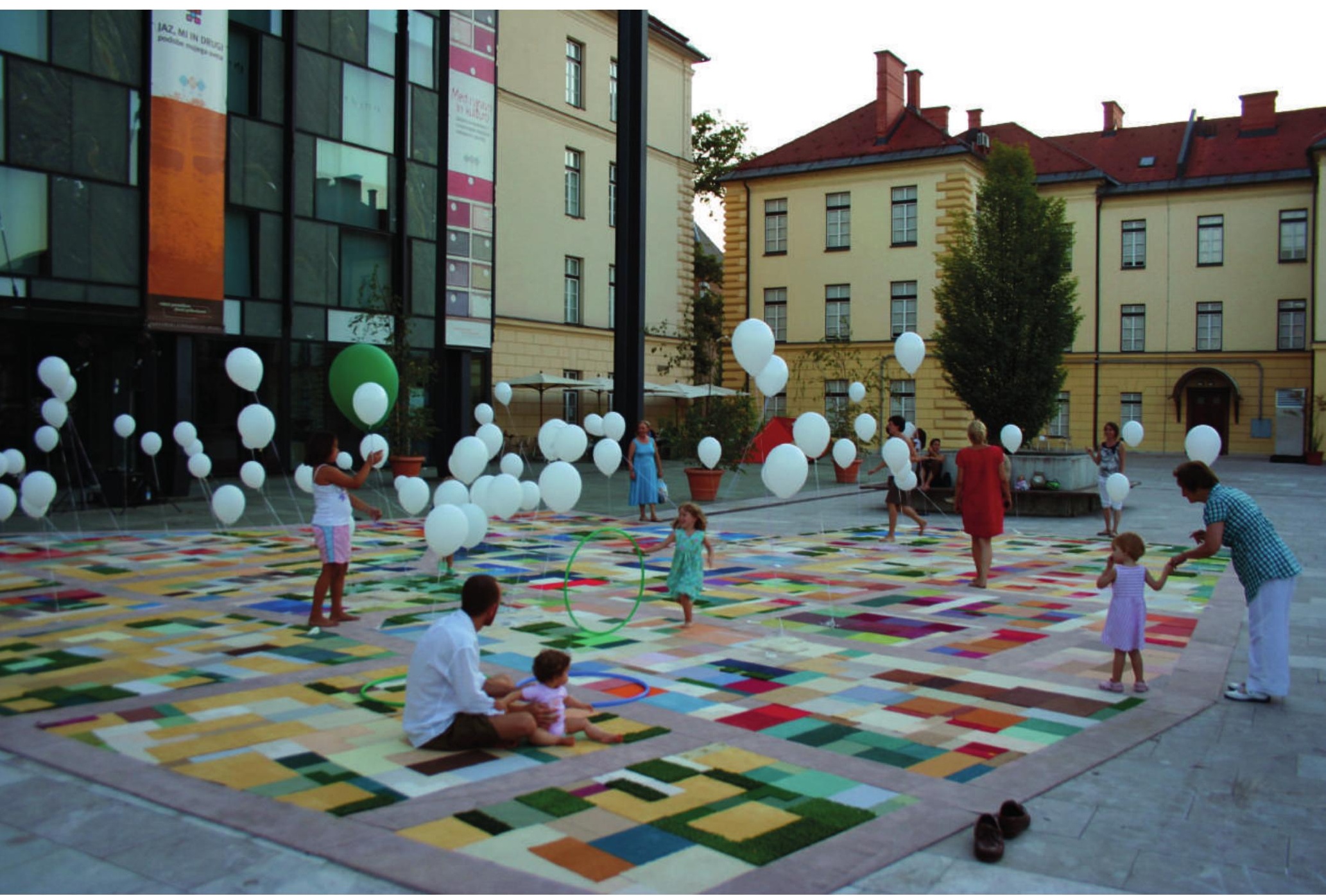

45 | The Journal of Public Space, 4(3), 2019 | ISSN 2206-9658

City Space Architecture / UN-Habitat 


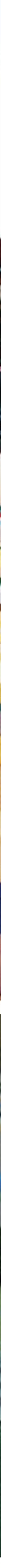

46 | The Journal of Public Space, 4(3), 2019 | ISSN 2206-9658

City Space Architecture / UN-Habitat 


\section{Čufarjeva street}

Photo credit: Dijana Vukojević

Due to the proximity of schools near Čufarjeva Street, almost two thousand children and teens walk through it every day. That is why it was important for Čufarjeva to become a safe and friendly street for pedestrians and bikers. With small interventions and through a change of traffic regime, we limited car traffic and enabled children and adults to walk, play and rest on the street care-free. The street's "furniture" was designed in collaboration with schoolchildren and high-school teens. The youngest ones helped us design interactive playground equipment through a series of workshops. Čufarjeva Street project is an important contribution to reducing car traffic in the proximity of schools and kindergartens. It also encourages parents to take their children to school by bike or on foot.

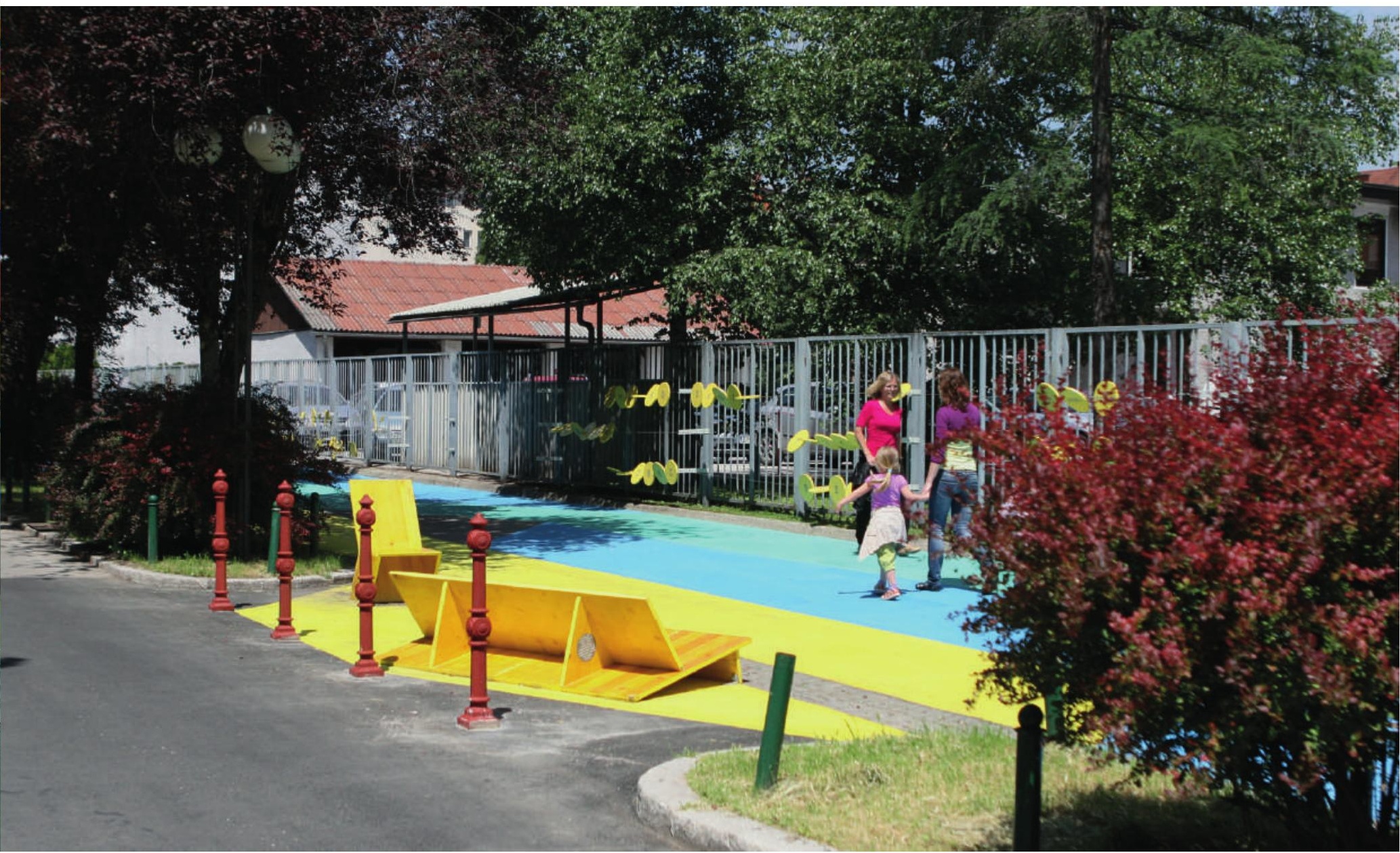

47 | The Journal of Public Space, 4(3), 2019 | ISSN 2206-9658

City Space Architecture / UN-Habitat 

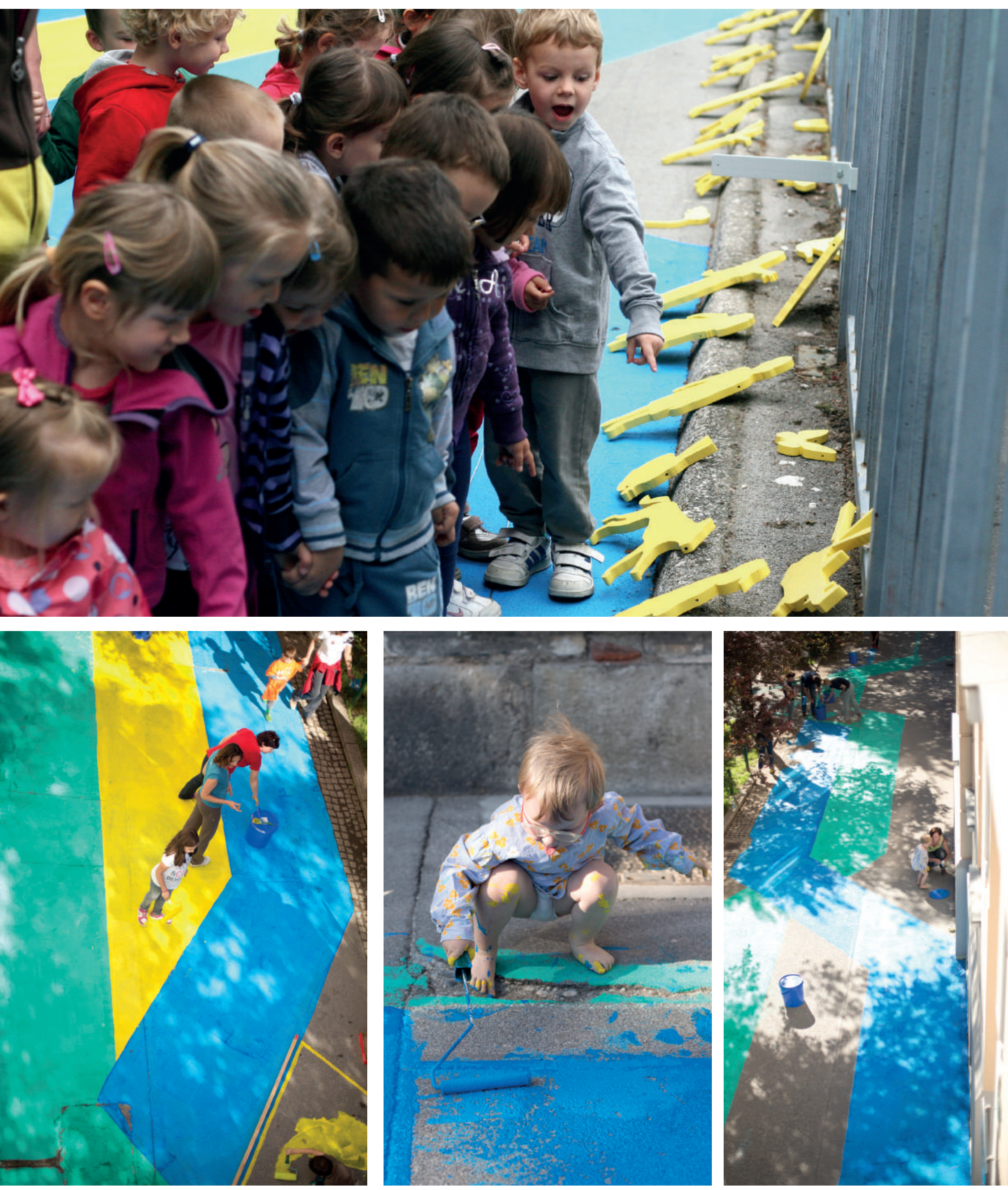

48 | The Journal of Public Space, 4(3), 2019 | ISSN 2206-9658

City Space Architecture / UN-Habitat 

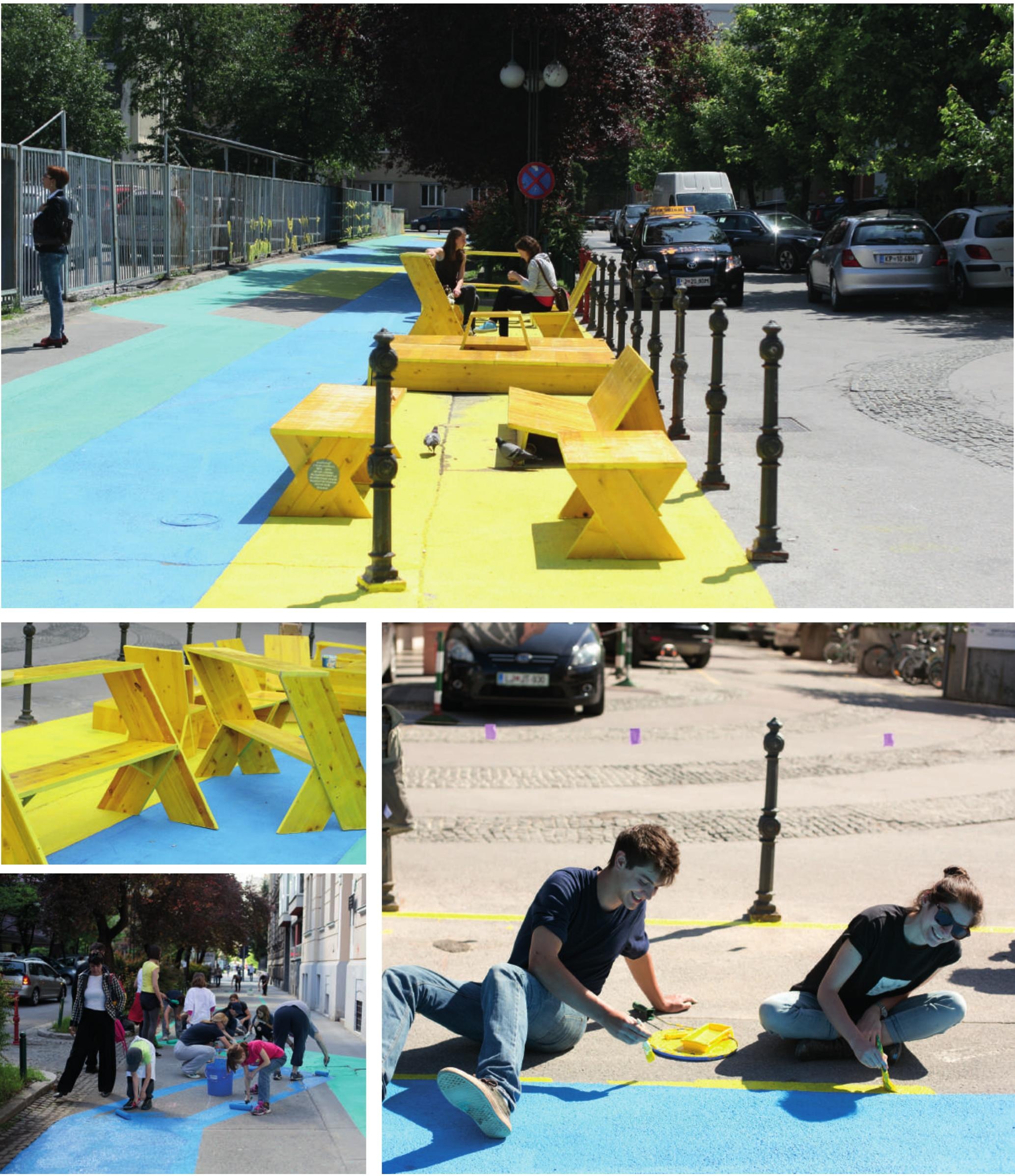

49 | The Journal of Public Space, 4(3), 2019 | ISSN 2206-9658

City Space Architecture / UN-Habitat 


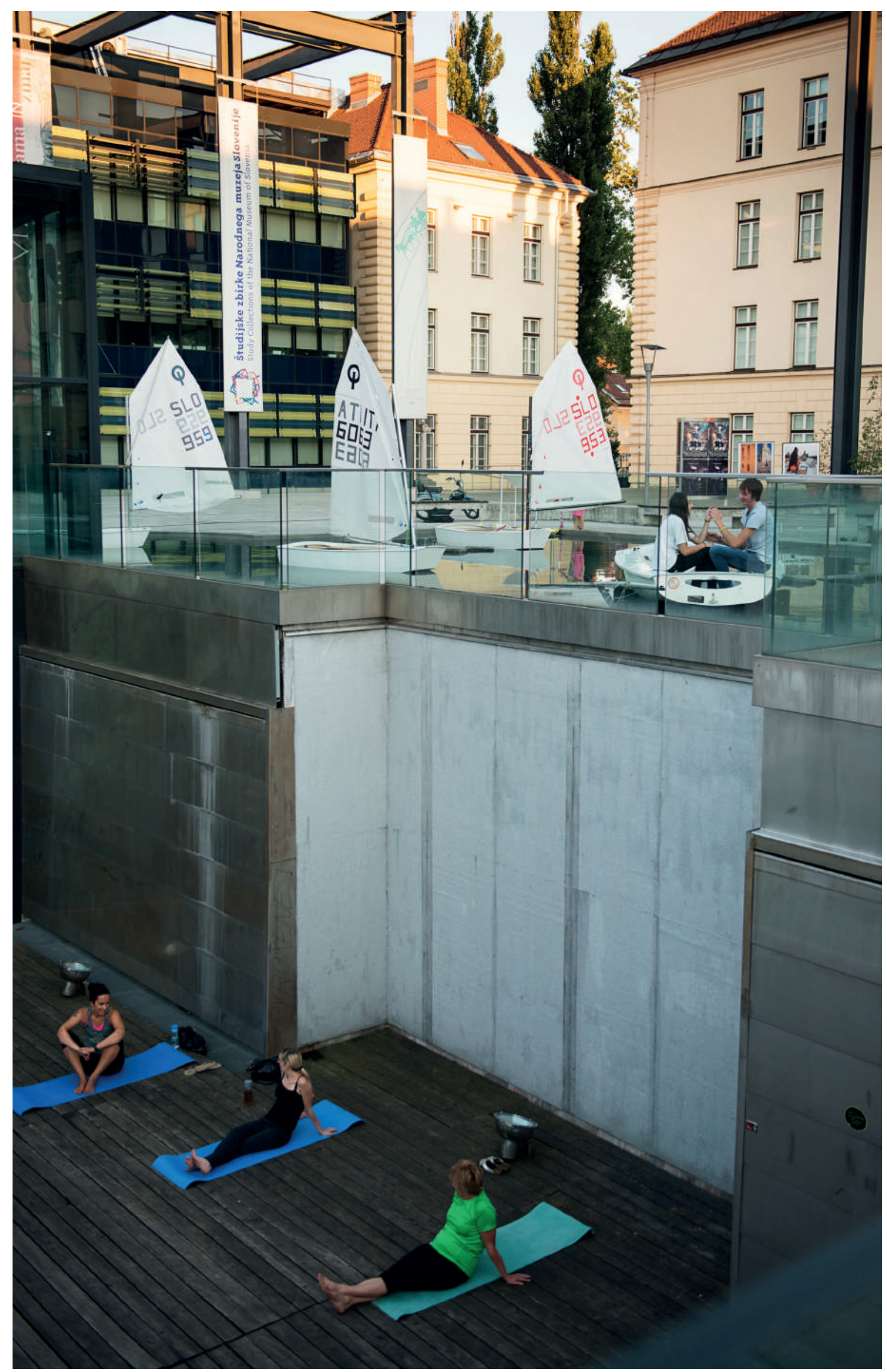

50 | The Journal of Public Space, 4(3), 2019 | ISSN 2206-9658

City Space Architecture / UN-Habitat 


\section{Optimists}

Photo credit: Matjaž Tančič

After ten years of stagnation, the owner of the Museum square in Ljubljana decided to renovate the abandoned fountain that is in the middle of the square and permanently fill it with water.As part of the U3, Triennial of Contemporary Art in Slovenia, we were invited to think of an installation for the fountain that would attract the local residents and others to socialize at the square. We placed four sailboats in the fountain. Passers-by had the opportunity to climb on the boats and enjoy the water. Parents and children alike enjoyed the fountain, and it quickly became an urban corner for adventure and socializing. The installation also contributed to the environmental improvement of the otherwise concrete museum platform that radiated with heat in the summer.

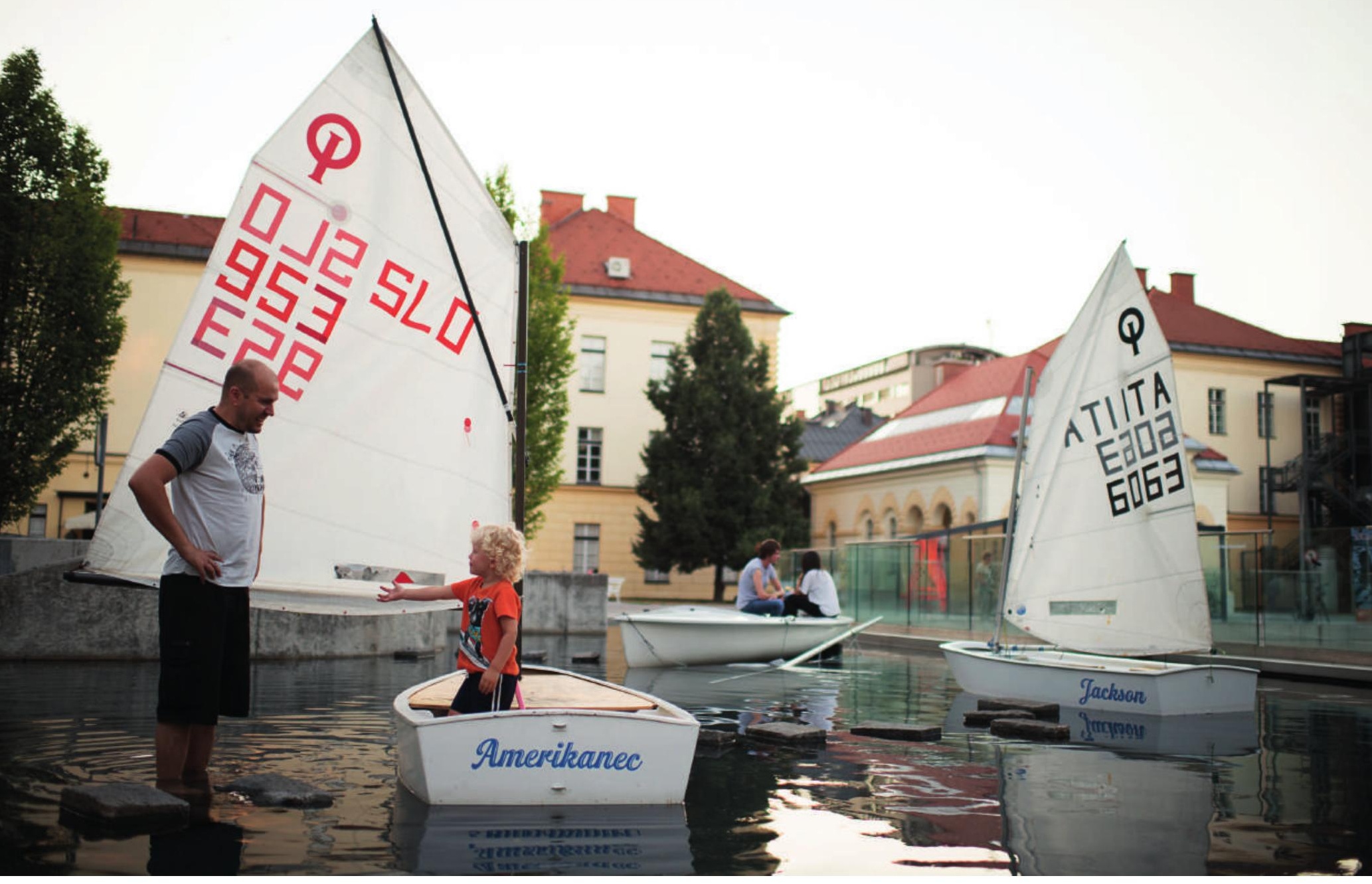

5I | The Journal of Public Space, 4(3), 2019 | ISSN 2206-9658

City Space Architecture / UN-Habitat 

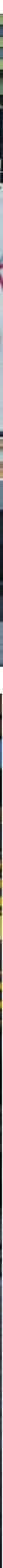


\section{Savsko Naselje Neighbourhood}

(2013-2016)

Photo credit: Matjaž Tančič

Savsko naselje is one of the first neighbourhoods constructed in Ljubljana afterWW2. In the past few decades, it regressed in social, spatial and economic sense. We started an Integrated Urban Regeneration project in Savsko naselje, initiated by the Department of Urban Planning of Municipality of Ljubljana. It was based on the inclusion of local residents and linking together of different organizations. Through organized and spontaneous community meetings we formed a programme for regeneration on several levels: social and cultural activities, sports, informal socialising, bottom-up spatial planning and a traffic plan for the neighbourhood. In two years' time, several experts, municipal institutions and NGOs have joined the process.

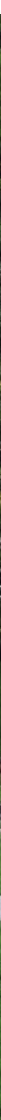


To Build the City on Temporary Success


Laving

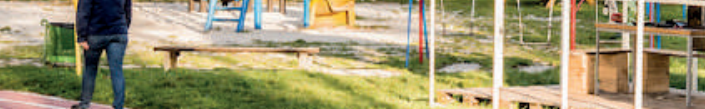

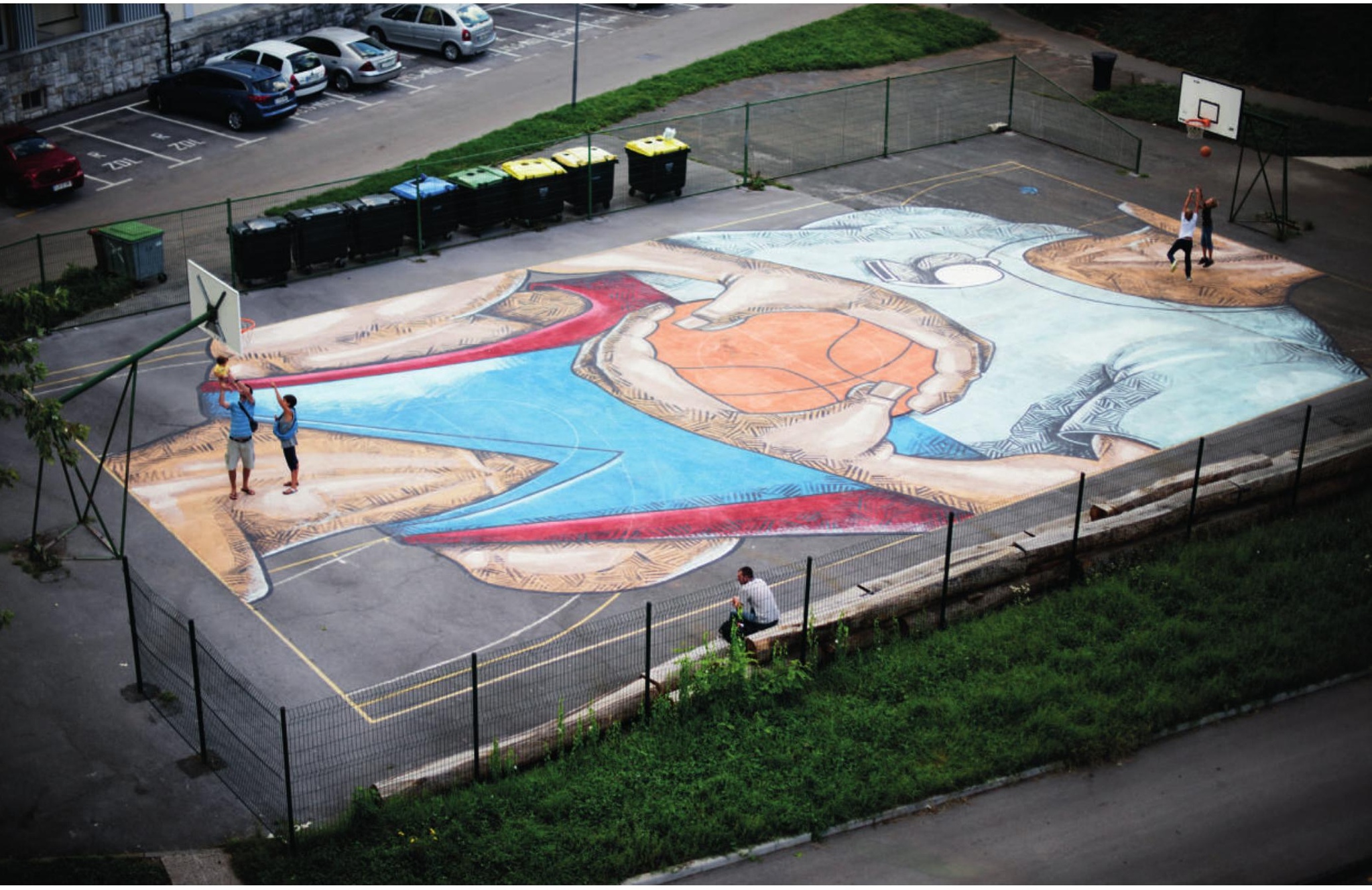

54 | The Journal of Public Space, 4(3), 2019 | ISSN 2206-9658

City Space Architecture / UN-Habitat 

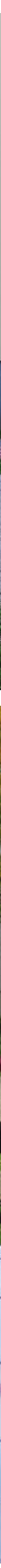

55 | The Journal of Public Space, 4(3), 2019 | ISSN 2206-9658 City Space Architecture / UN-Habitat 


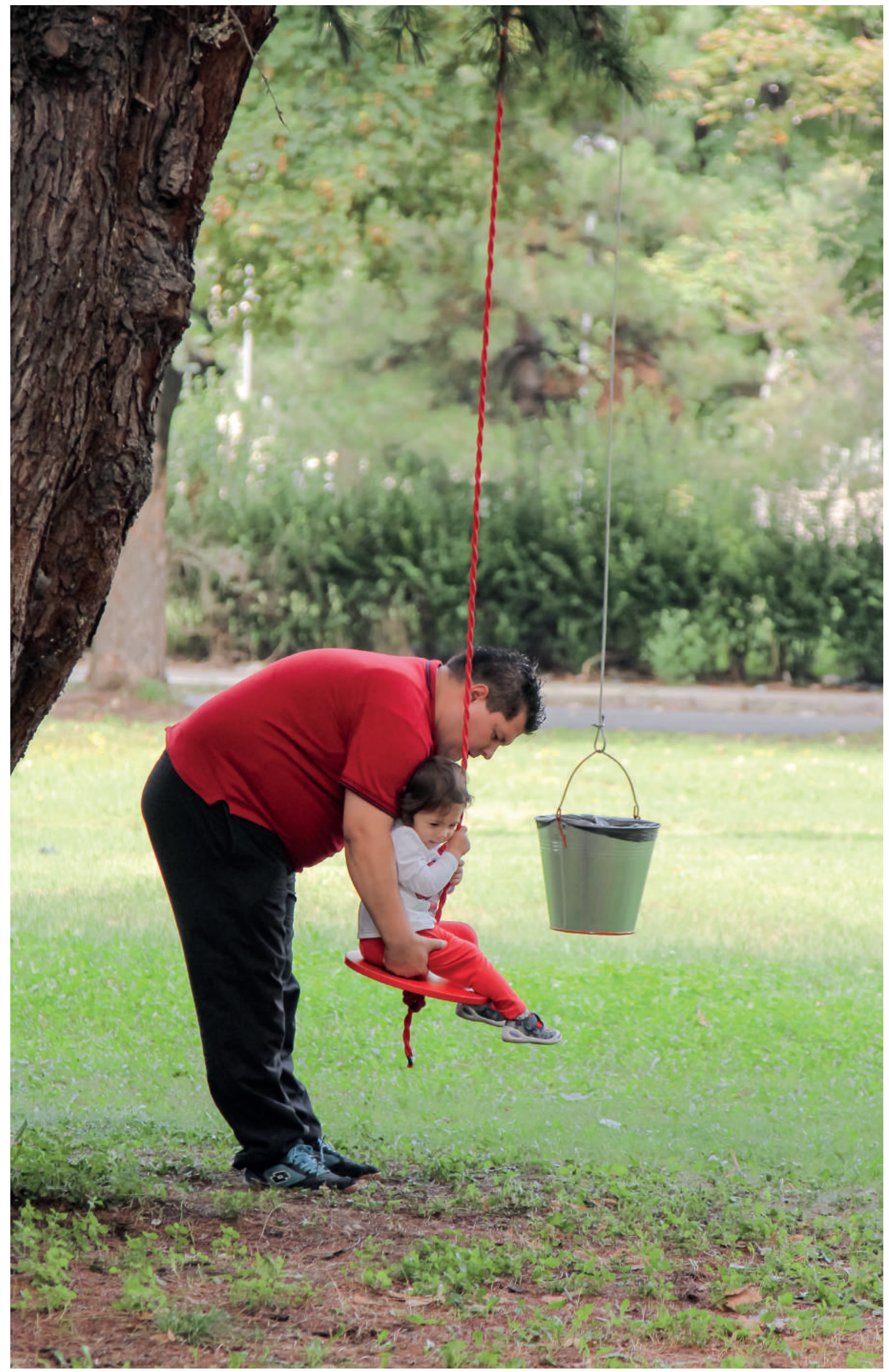

56 | The Journal of Public Space, 4(3), 2019 | ISSN 2206-9658

City Space Architecture / UN-Habitat 


\section{Meeting Places Skopje}

(2014)

Photo credit: prostoRož

Public playgrounds were a response to an overall lack of public space initiatives in Skopje. They were based on personal interpretations of public spaces by nine students from five countries. The students focused on public spaces around the local youth cultural center. Through open access of public spaces to various social groups, the students tried to understand the variety of uses of public spaces. A series of ideas for interventions was created from already existing unused urban elements. They were incorporated in a way not to disturb the flow of activities detected on the location, but to improve their use and quality. Immediate reactions of the by passers proved that small and smart interventions can easily test and point at possible scenarios for alternative use of public space.

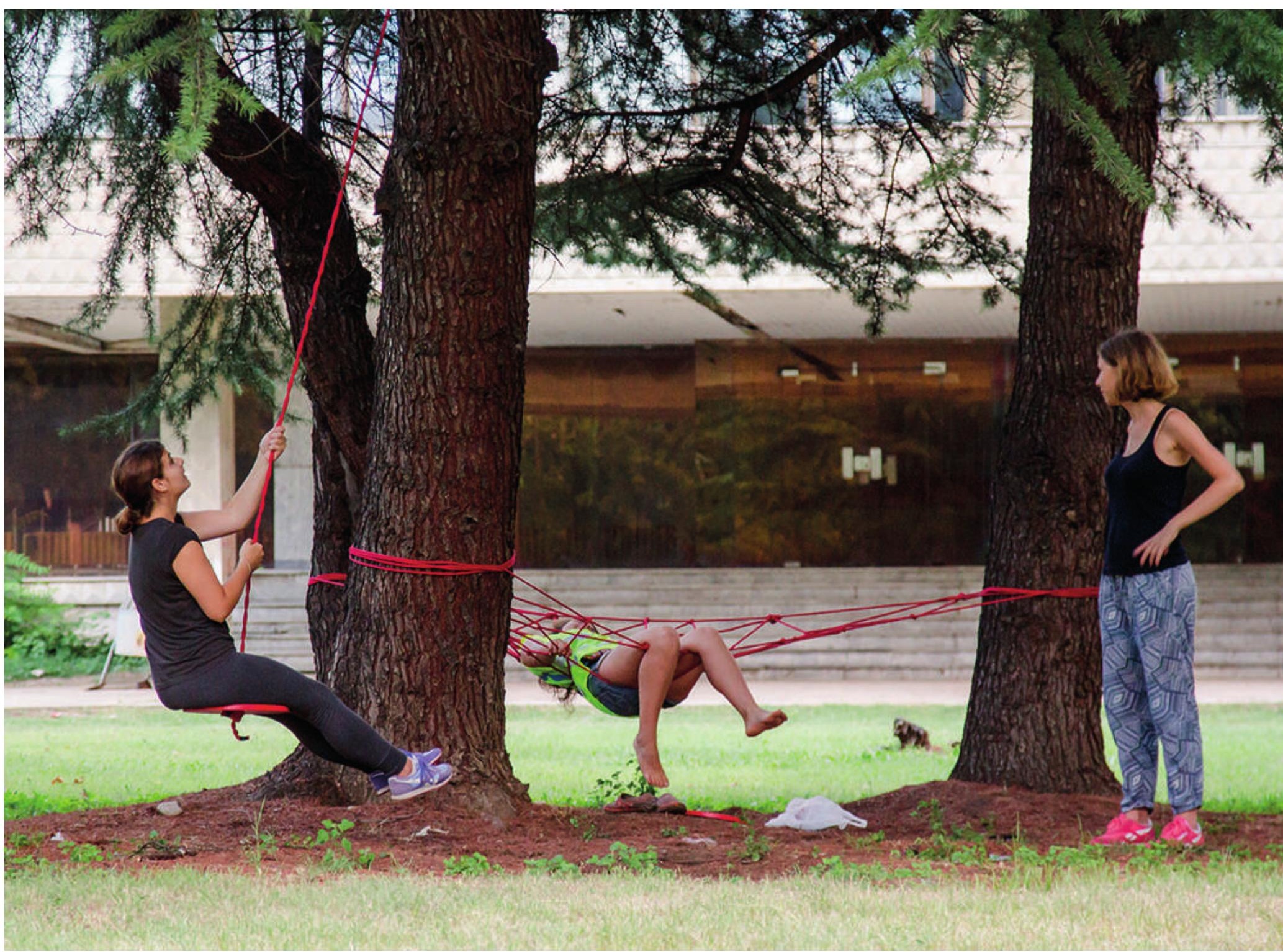

57 | The Journal of Public Space, 4(3), 2019 | ISSN 2206-9658

City Space Architecture / UN-Habitat 


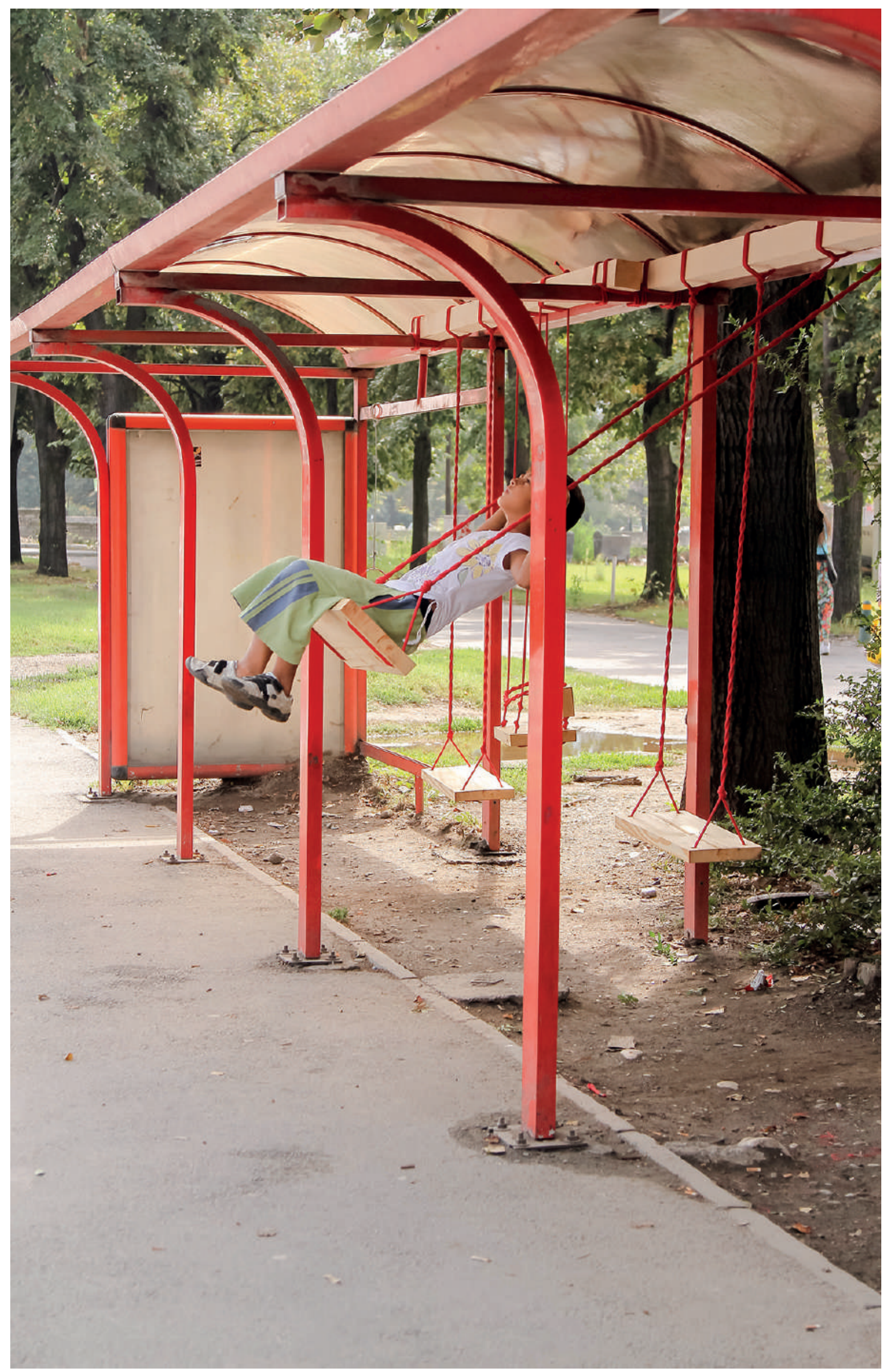

58 | The Journal of Public Space, 4(3), 2019 | ISSN 2206-9658

City Space Architecture / UN-Habitat 

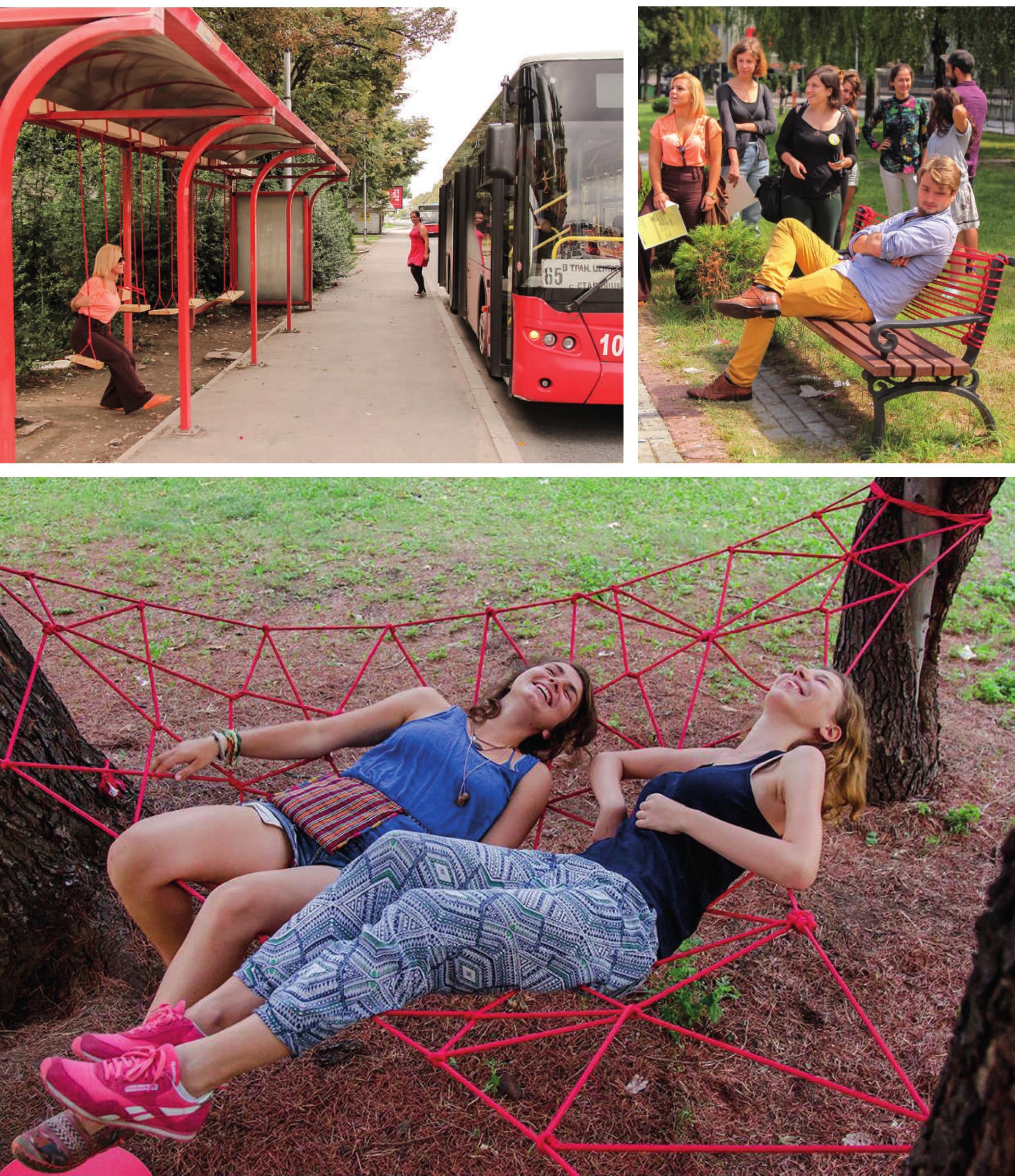

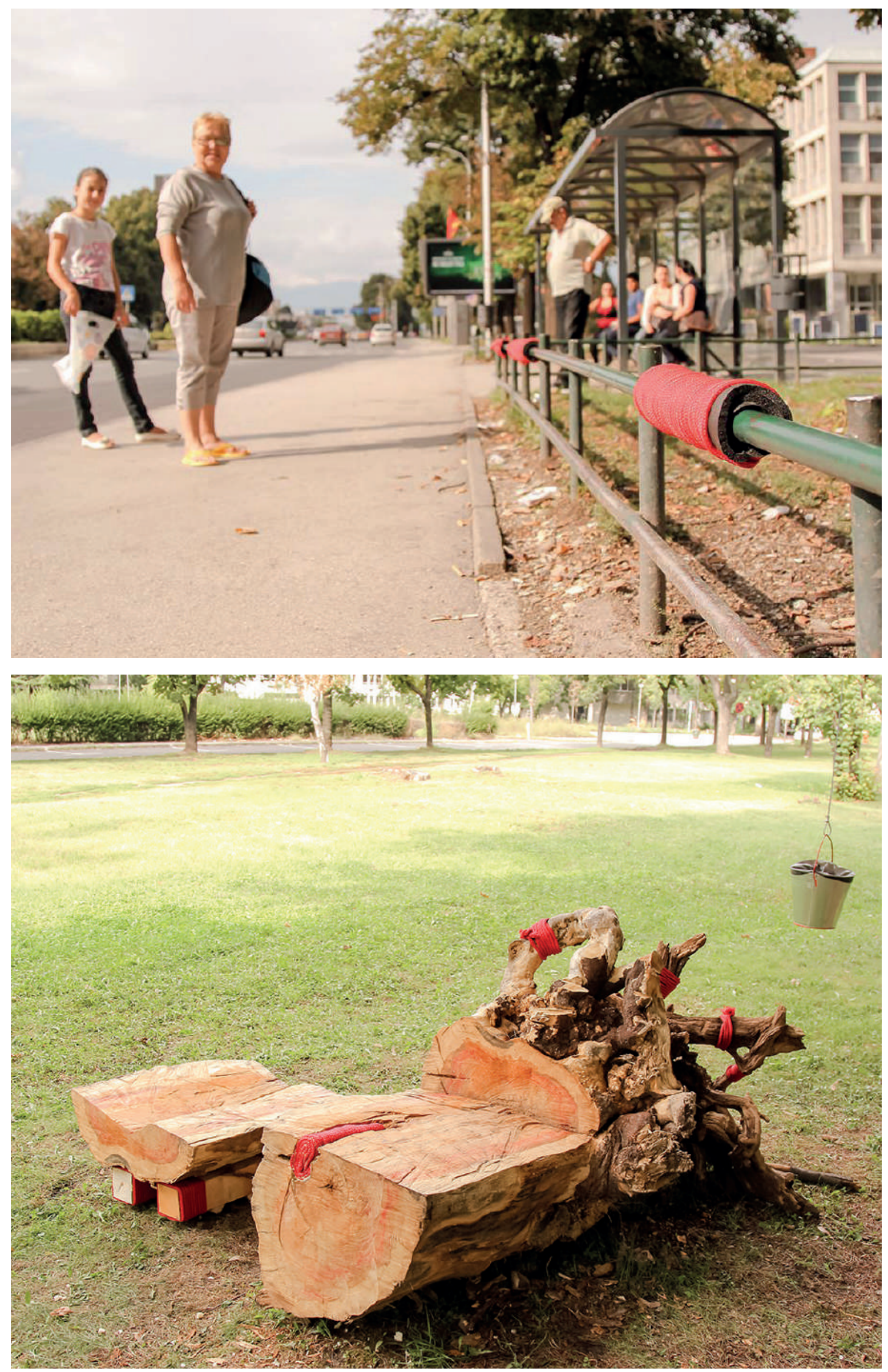

60 | The Journal of Public Space, 4(3), 2019 | ISSN 2206-9658

City Space Architecture / UN-Habitat 